\title{
The Status Of A Husband Married According To His Wife's Religious Rules But After Divorced Returning To The Kinship System Of Balinese Customary Law (Case Study In Antura Village, Buleleng Regency)
}

\author{
I Made Arya Utama; Gede Ngurah Agus Suhardiyana; I Ketut Widia; I Wayan Rideng \\ Magister of Law, Postgraduate Program Warmadewa University, Denpasar, Bali
}

\begin{abstract}
Many legal, social, cultural, and religious implications arise from each marriage that takes place. This is a legal consequence of the receipt of various kinds of customary customs that originate from the religious law adopted by the local community. This study aimed to find out the status of men who convert in the Balinese Customary law system and to find out the status of men who convert to the original family after divorce in the village of Anturan, Buleleng Regency. The type of research used in this study is empirical legal research. The types of approaches used in this study are legal approaches (statute approach), conceptual approaches, case approach and historical approach. Sources of legal material used are primary and secondary legal materials, by recording and documents and analyzed descriptively. In conclusion, factors that cause a person to convert religion are 1) Confidence factors, 2) Environmental factors, 3) Factors of poverty, 4) Family factors, 5) Factors of community leaders, 6) Political and war factors, 7) Factors already falling love. The status of a man who has converted his religion, then divorced legally is, will return to remain as an heir with all the rights and obligations attached, but will get inheritance with the consequence of carrying out obligations or swadrama and obtaining rights referred to as swadikara. Because the status has been returned to the family, the rights and obligations in the community, especially in the village of Pakraman can be accepted as village, officials or community members.
\end{abstract}

Keywords: status of man; conversion; divorce, family origin

\section{Introduction}

As an inner bond between a man and a woman to form a happy family based on the One Godhead, marriage institutions have very complex social implications that require comprehensive handling. The institution of marriage as the smallest social institution of a large nation like Indonesia has very strategic functions and roles in order to realize the ideals of nation-building, that is to create a fair and prosperous society based on Pancasila. The prosperity of each household, this is an indicator of the success of the community with the government in building the nation and state. Especially if it is supported by a healthy 
investment climate, there will be many investors who are willing to invest large sums of money to jointly realize prosperity. It is indeed inseparable between the welfare of the community and the success of the government to condition various types of potential. What meant is, security and public order and investment climate both in the field of land and in other fields. Lately, there have been things that can be witnessed by the senses and can be explained and assessed scientifically related to the high level of divorce that occurs in society. Even though at the beginning of courtship or marriage a household is full of genuine love, the fact is that not a few households run aground and take a divorce shortcut with all the consequences. If identified, there are many factors that cause divorce. The most dominant are economic factors. The poverty that ensnares a family can lead to a tragic divorce because it can sacrifice children and extended families. If a family is not poor, lives well and is well-off, then all problems both small and large can be solved with money. But on the contrary, if money does not have and poverty is very close, then small problems can become large and cannot be resolved. Finally, taking a path that is actually disliked by God, but also not prohibited by God, that is divorce. In addition to the economic factor of the family that is not yet prosperous, it turns out that different factors of religion in one family are also one of the triggers for divorce. It is not easy to construct a way of thinking someone who is willing to change his own religion, but in reality, is still very strong with the beliefs held before the marriage takes place. In other words, when the way of marriage according to religion is carried out, those who change their own religion for the sake of marriage do it insincerely, even though it seems to be serious. Especially those who are Hindu in Bali who submits themselves to Balinese customary law sourced from Hinduism, those who convert to religion already mean leaving swadarma and self-reliance or giving up all their rights and obligations in their original family, [1].

Previously, this study have been conducted by some researchers such as in [2], [3] and [4]. The study of Widetya et al (2015) are focused on the consequences of divorce law against the position of women of nyerod marriage of different castes according to Bali's indigenous kinship law. The findings of this study showed that Balinese traditional marriage want the same caste position between the bride and groom. Marriage with a different caste is forbidden in ancient times, but now it is legalized by Paswara DPRD Bali No. 11 of 1951, but the implementation is lacking especially related to the implementation of caste or ceremonial lowering patiwangi. This causes the position of women become blurred especially when there was a divorce. [3] also conducted the similar study which focused on dynamics of Balinese marriage status and position of sentana rajeg children according to customary law and Hindu law. The results of this study showed that it is found based on the research that 'sentana rajeg' has become the term to be the problem solver within the wedding system in Bali. This term is obviously based on the teaching of Hinduism in Rg. Ve- da. The sentana rajeg is caused to be effective in accordance with the Hindu script of law, Manawad- harmasastra IX.127-140. Considering the Balinese traditional regulation, the condition of sentana ra- jeg has given an opportunity for the position of the anak sentana to be legalized through the tradition- al process in a sentana institution because of the philosophical values and the teaching of Hinduism embedded within. One of its functions is that the sentana rajeg may be used to avoid the revocation of right called camput as well as to maintain the traditional obligations, ayahan, on the parahyangan, the pawongan, and the pawongan. Moreover Ananta et al (2017) also conducted the similar study which focused on divorce and its legal effects on children and joint assets according to Osing customary law in Aliyan village, Rogojampi district, Banyuwangi regency. The finding of this study showed that according to Osing adat law in Aliyan village, Rogojampi, Banyuwangi Regency, the divorce will give the rise to rights and 
obligations of children and joint property. The community of Osing adat law embraces the system of bilateral kinship which pulls the descendant line of the second parent with regard to the divorce by which children are given the freedom to choose by following the father or the mother. The community of Osing adat law never discrimi- nates on the ground of biological children, legal children, adopted children and stepchildren, and legal position children. In the system of bilateral kinship, with regard to the divorce, the legal position of the property will return to the origin and joint property will be shared equally.

Problems will be complicated to solve when for something and other things different households of this religion must end their happiness with divorce. This study examined and provided in-depth answers to the problems below. Thus, based on the background and the latest related studies above, this study aims to find out the legal position of husbands who convert his religious in Balinese Customary Law kinship system in the village of Anturan and to find out the legal position husband who returned to embrace the religion of origin in the status customary law in the village of Anturan.

\section{Methods}

The type of research used in this study is the type of empirical legal research, with the type of field approach by making observations in the community about the fact that the incident is a research study. Types of legislation approach (statute approach), conceptual approach, case approach, historical approach are the approach used in this study. All legal data that has been collected is interpreted based on the legal interpretation method so that it is in accordance with the formulation of the problem that has been determined. After the legal material is analyzed, then it is presented in a systematic descriptive manner.

\section{Results And Discussion}

Grounded by the purposes of this study, thus based on analysis, it derived the result of the study which described in the following discussion.

\subsection{Motivation to Convert Religion in the Anturan Village, Buleleng District, Buleleng Regency}

The population of Anturan Village is very dense or large, not less than 10,000 people or 3655 heads of families. Most of the population work as farmers, there are also fishermen, civil servants, Republic of Indonesia Armed Forces, labourers and some who work in the service sector. In general, the villagers of Anturan have been freed from the predicate of the poor. On average, residents' houses are very decent and may be said to tend to be luxurious. The tourism industry is supporting the first and foremost why the Anturan villagers have become prosperous and orderly in increasing their development so far. Religion as a manifestation of a fixed belief in the existence of God Almighty and sincere recognition of the power of God has a function in order to nourish the mentality of mankind and become the guide of life to achieve inner happiness, [5]. In the Unitary State of the Republic of Indonesia which is very democratic and built on Pancasila, religious freedom is very high. People want to embrace religion or otherwise do not embrace any religion, as long as they believe and believe in the existence of God Almighty, guaranteed by the constitution. Switching religion along the right 
procedures is also not prohibited in Indonesia based on Pancasila. Therefore, it is not surprising that every day there are people who convert to various reasons

Of these six religions, all are open, meaning that traffic is converted to religion. Today is Hinduism the day after tomorrow changing religion to Islam is totally hopeless. Likewise, since birth, Muslims are already Muslim, for reasons of poverty; they cannot feed their wives and then convert to converts to other religious teachings so that they can move according to what they want or according to what is believed for those who convert themselves. There are many conditions that make a person including Balinese finally decide to convert.

It was identified that there were 5 (five) reasons that Balinese who were originally Hindus decided to convert, those are

1) Most Hindus in Bali eventually converted because of falling in love with people who happened to be non-Hindu.

2) They wanted to change the fate of moving to a religion that is explicitly offered offers an easy way to get out of the poverty pit. These poor families were indeed the first to be able to conjure up their houses into permanent ceramic-floored buildings in just a few months, after conversion.

3) Still with the motivation to convert because of poverty, another reason that is widely used as a basis for converting religion is that being Hindu is a hassle and the cost is very high. They forget and think in other places they never spend money and always get help, whether it's rice, wheat, sugar, coffee and so on. Indeed, the number of religious ceremonies and customs that incur costs is not a little reason used to convert to the religion. A little ceremony, a little traditional ritual. Besides being very troublesome, it is said that they are high cost and burden their lives.

4) Regarding All Religion the Same "Recently there have been ideas from Western countries, European regions, Americans who think that any religion is the same, all teach the truth, the most important thing in life is doing good and not disturbing the environment, especially harming others. The noble values that already have ancestral heritage are very good to be applied in daily life. Religion besides making a burden, it also becomes a symbol and motivation to commit violence, arson, and murder in the name of God and religion.

5) Regarding Religion is not important. Of the many Balinese who convert, whatever the background of the case, it is very likely that some consider religion to be insignificant. As for those who want to be Hindu or other religions it is absolutely not something that needs to be seriously considered.

The most appropriate reasons to move religion. Although they had never revealed it to the public, the final decision to convert was clearly showing this. If not, where might they decide so. None of the Balinese converts without any attempt to keep their religion from birth. The problem is that there is a lot of hard work from the outside to ensure that Balinese people are willing to convert that is by imposing new understandings.

\subsection{Legal Position of a Husband Who Married According to Religion Wife After Divorce in Anturan Village, Buleleng Regency}

The legal position of a husband who has converted from a religion adopted from birth to a new religion that will be adopted after marriage or other religions, then he will lose his status as heir. The logic of thinking is because boys who convert to religion are the same as leaving their obligations as children or heirs so their rights to inheritance are lost.

Based on customary law, especially those that apply in the Village of Anturan, Buleleng Regency, the status of a boy who has moved his religion, then divorced legally, and returned 
to his original home is, will continue to be a heir legally, so that all rights are returned and its inherent obligations as an heir. In order to restore status as an heir, there are several religious and customary processions that must be followed. After that, it is possible to claim inheritance with the consequence of carrying out obligations or swadrama and obtaining rights which are called swadikara. Because the status has been returned to the family, the rights and obligations in the community, especially in the village of Pakraman, can be accepted as karma (member of the Pakraman village). According to Suwena, (2017) Upadesha, Chairperson of the Main Assembly of the Pakraman Village in Bali Province, "It was determined based on the results of the 2006 Pakraman Village Council Supreme Court, that the Pakraman Village Assembly in Bali at various levels as a case-breaker institution was purely a decision final and binding".

Taking into account the above opinion, the purely indigenous problems that occur in the family of I Made Selat can be resolved based on local law called awig-awig and perarem agreed upon by the traditional village krama in the village of Anturan.

After the status of an heir was returned, a new legal issue arose concerning custody of children after divorce. For this matter, there are many models that exist in the community. As a comparison, it is better to convey the models in question. The obligation of ex-husband and wife after post-divorce to provide a living for children is one of the consequences of divorce, which we can see in the provisions of Article 41 of Law Number 1 of 1974 concerning Marriage. In this provision it is regulated due to the termination of marriage because divorce is:

a) Both the mother and father are still obliged to care for and educate their children, solely based on the interests of the child; if there is a dispute regarding the mastery of children, the Court gives its decision.

b) The father is responsible for all the maintenance and education costs that the child needs; if the father is in fact unable to fulfill these obligations, the Court can determine that the mother is carrying the costs.

c) Courts can require ex-husbands to provide livelihood costs and/or determine obligations for ex-wives."

Noting the sound of the article can be seen that the obligation to provide, in the sense of being responsible for all the costs of maintaining and educating decision, the mother will bear the costs. However, it should children after divorce, is with the father. However, if father cannot fulfill the obligation in reality, on the court also be noted, the obligation to maintain and educate children remains in the two parents even though they have divorced. Taking into account these provisions, this means that even if there is a divorce the obligation of husband and wife to take care of children, including providing a living, must still be carried out. Frequently the question arises, what about giving a living to stepchildren.

To answer the question about whether you are obliged to provide for stepchildren after divorce, then referring to the concept of civilization between stepchildren and their parents, it is certainly not mandatory to care for stepchildren. But if it is capable, of course, it is not prohibited to maintain stepchildren. Still based on the same habits, basically, stepchildren only have inheritance and civil relations with their own blood parents. In addition, there is also the assumption that stepchildren are not heirs. In this case, parents and stepchildren may not have civil relations because parents are not parents who are bloodied with the child. This also means that divorced husbands or wives have no obligation to provide support to stepchildren 


\section{Conclusions}

Based on the description and discussion above, as well as the analysis carried out on the purposes of this study, thus it can be concluded that: a) factors that cause a person to convert towards his religion. In the social sciences display the argument that education plays a strong role in the formation of one's religious disposition. Furthermore, it was found many facts from the establishment of religious schools led by various religious foundations. The fact shows that only a small proportion of the total number of students from these schools entered the religion that was embraced by the founder's religion. Only to the extent that can be justified that the education system through schooling is a factor that causes people to convert. b) the legal status of a husband who has moved his religion, then divorced legally is, will return to remain as heir with all the rights and obligations attached. But will get inheritance with the consequence of carrying out obligations or swadrama and obtaining rights referred to as swadikara. Because the status has been returned to the family, the rights and obligations in the community, especially in the village of Pakraman can be accepted as village officials or community members.

\section{References}

[1] Windia, Butir-butir Tercecer Hukum Adat Bali. Denpasar: Udayana Press University, 2008.

[2] A. B. C. Widetya, R. Sulistyarini, and R. D. Puru, "Akibat Hukum Perceraian Terhadap Kedudukan Perempuan dari Perkawinan Nyerod Beda Kasta Menurut Hukum Kekerabatan Adat Bali," J. Huk., 2015.

[3] K. Hemamalini, "Dinamika Perkawinan Adat Bali: Status dan Kedudukan Anak Sentana Rajeg Menurut Hukum Adat dan Hukum Hindu," Dharmasmrti, vol. XIII, no. 26, pp. 1-135, 2015.

[4] M. J. Ananta, D. Rato, and I. W. Yasa, "Perceraian dan Akibat Hukumnya terhadap Anak dan Harta Bersama Menurut Hukum Adat Osing di Desa Aliyan, Kecamatan Rogojampi, Kabupaten Banyuwangi," e-Journal Lentera Huk., vol. 4, no. 3, p. 221, 2017.

[5] Adiprawira, Pendidikan Agama Hindu Untuk SD. Jakarta: Depdinas, 2012.

[6] J. G. P. Suwena, Juklak dan Juknis Tata Cara Penyelesaian Wicara Oleh Majelis Desa Pakraman di Bali. Denpasar: MUDP Bali, 2017. 